\title{
Short-term and long-term Interconnectedness of stock returns in Western Europe and the global market
}

\author{
Ajaya Kumar Panda ${ }^{1 * \dagger}$ and Swagatika Nanda ${ }^{2 \dagger}$
}

* Correspondence:
akpanda@nitie.ac.in;
ajayapanda80@gmail.com
${ }^{\dagger}$ Equal contributors
${ }^{1}$ National Institute of Industrial
Engineering, Powai, Mumbai, India
Full list of author information is
available at the end of the article

\begin{abstract}
Background: The present study examines the short term dynamics and long term equilibrium relationship among the stock markets of 17 countries in Western Europe as well as the world market, using time series techniques.
\end{abstract}

Methods: Weekly returns of market benchmark indices of the respective countries are used from the second week of 1995 to the fourth week of December 2013.

Results: The study finds that the market returns of Austria, Belgium, the Netherlands, and France are relatively less dynamically interlinked as compared with Britain, Denmark, Finland, Germany, Portugal, Spain, Sweden, Switzerland, Greece, Ireland, Luxembourg, and Norway, which are quite dynamically interlinked within the region as well as with the $\mathrm{MSCl}$ world index.

Conclusion: There exists a strong long run equilibrium relationship between the return distributions of the stock markets within the region.

Keywords: Stock market interlinkages, Cointegration, VAR, VECM, MSCI

JEL Classification: C22, F36, G15

\section{Background}

Investors wish to hold securities from a variety of firms/ sectors or from different countries, because such diversification will reduce portfolio risk. Similarly, investors who buy shares in foreign as well as domestic companies seek to avoid elements of market risk and reap the rewards that follow from global diversification. Diversification pays, since stock indices of different countries do not necessarily move together, meaning that stock returns in different markets are less than perfectly correlated. Hence, identifying the inter dependences between the stock markets becomes an important issue for researchers, as well as for policy makers who aim to capture its impacts on capital flows. Better understanding of the nature of cross market linkages and interactions could therefore be of help to investors and policymakers alike. The concept of stock market linkages is based on two theories, namely integration theory and diversification theory. Integration theory treats markets as integrated when returns are determined only by common risk factors. Estimates made under the assumption of integration employ the CAPM model. The null hypothesis of full integration requires that the local portfolio is only priced relative to the global portfolio; thus, expected

(c) The Author(s). 2017 Open Access This article is distributed under the terms of the Creative Commons Attribution 4.0 International License (http://creativecommons.org/licenses/by/4.0/), which permits unrestricted use, distribution, and reproduction in any medium, provided you give appropriate credit to the original author(s) and the source, provide a link to the Creative Commons license, and indicate if changes were made. 
local returns in a fully integrated market depend only on non-diversifiable international factors. Diversification theory as per modern portfolio theory talks about portfolio diversification, which makes risk-averse market agents tend to maximize portfolio return and minimize portfolio risk by making up their portfolios with low correlation assets. At the international level, if returns from investments in different national stock markets are not perfectly correlated and the correlation is stable (which means that low volatility of correlation is observed), there exist potential gains from international portfolio diversification. On the other hand, if international stock markets share common trends, this will imply no significant gains from portfolio diversification. From this theoretical base, this study intends to provide a clear picture of the stock markets of Western Europe and their volatility over a significantly long span of time;and to suggest preferences for international diversification.

A large body of literature has focused on various aspects of financial integrationfrom a range of economic and financial stand points. Some earlier studiesfocused on testing the time series properties of stock markets and identifying their interlinking coefficients. There is a substantial literature that addresses theoretical and empirical issues involved with inter market linkages among national stock indices. Efficient markets arguments suggest that, in the absence of market imperfections, a stock index reflects all available information, including that captured by any other country's stock index. If different markets are related, there should be no systematic lagged inter market adjustments long enough or large enough to exploit. Empirical results typically reveal significant correlations only across markets that are located in proximate geographic areas, with no substantive links between markets across wider zones.

We take a dynamic simultaneous equations model that is specified to reveal the contemporaneous and lead-lag relationships among the weekly rates of return of different national market indices. This enables us to identify how the magnitude and statistical significance of each response has changed overtime. The model is estimated using returns across 17 national equity markets in Western Europe for the 17 years spanning 1995 to 2013.

In view of the above discussion, the present study first aims to explore the dynamic interlinkages and long run equilibrium relationships among 17 national stock markets in Western Europe and a world index. The world market presented by MSCI is considered with the sample in order to trace out the interlinkages of the stockmarkets under investigation with the world market. In order to capture the dynamic interlinkages between the stock markets, the present study uses variance decomposition techniques and a vector error correction model.

This study is primarily motivated by the reasons discussed below. First, most studies that examine the interdependences between international stock markets use cointegration methods and then indirectly test the stock market integration hypothesis.

The present study also employs a cointegration technique using maximum likelihood test statistics. Second, since a number of studies have documented how international equity market integration changes overtime, the inclusion of a longer sample period permits us to investigate the extended impact of changes in world stock markets on the degree of integration.

Unlike previous studies, the present study includes a global market index-MS$\mathrm{CI}-$ as an index to test the integration between them. Third, empirical papers directly 
investigating stock market integration have mainly been limited to developed markets, with few studies tending to focus on emerging markets. This paper attempts to study all developed and emerging markets of the Western European region on the same platform.

The rest of the paper is organized as follows: Literature review provides a review of selected literature, Nature and sources of data describes the statistical data, Methods presents the methodology, Analysis of empirical findings discusses the empirical findings, and Conclusion concludes the study.

\section{Literature review}

In this section, we focus on studies examining the interlinkages between stock markets and their co-movements across specific regions and countries, using various methodologies. A few studies have used VAR models, while others have employed the Generalised Autoregressive Conditional Heteroscedasticity technique. Some studies have used causality and cointegration tests in order to check the markets' short-term and long-term co-movements. A few studies focused exclusively on European regionare also reviewed.

Eun and Shim (1989) investigate the international transmission mechanism by estimating a nine-market vector autoregression (VAR) system and find a substantial degree of multilateral interaction among the stock markets. Innovations in the U.S. market are rapidly transmitted to other markets, where as no single foreign market can significantly explain the U.S. market's movements. Phylaktis and Ravazzolo (2002) measure financial linkages by analyzing the covariance of excess returns on the national stock markets of emerging economies. Kasa (1992) examines the existence of common stochastic trends as a driver of cointegration by applying multivariate cointegration to five well-established financial markets. In a similar vein, the long-run co-movements between markets are studied by Chung and Lin (1994) in Japan, the U.S., Taiwan, HongKong, and Singapore over the period 1985-92, finding weak financial linkages. Corhay et al. (1995) undertook a similar analysis for Australia, HongKong, Japan, Singapore, and New Zealand over the period 1972-92; as did Masih and Masih (1999) for the U.S., Japan, the U.K., Germany, Singapore, Malaysia, Hong Kong, and Thailand over the period 1992-97. Samitas and Kenourgios (2011) investigate stock market integration in a number of Balkan countries and compare it with the level of integration among several developed markets (the U.S., Britain, and Germany) in 2000-2006. Using several cointegration tests, the results support the existence of long-term relationships among Balkan stock markets and developed markets. Phylaktis and Ravazzolo (2005) examine the stock market linkages of a group of Pacific-Basin countries with the U.S. and Japan by estimating ARMA over the period 1980-1998 and find that the relaxation of restrictions may have strengthened international market interrelations and that country funds have provided access to highly regulated capital markets.

A good number of studies investigate the short and long-term linkages across the European region, as well as across Central and Eastern European stock exchanges, both in terms of stock returns and stock market volatility. Gilmore and McManus (2002) and Gilmore and McManus (2003) cannot conclude that any long-term equilibrium relationship exists among Central and Eastern Europe stock 
exchanges markets. However, Voronkova (2004) finds evidence of long-run links among the European stock markets. Along similar lines, Syriopoulos (2004) and Scheicher (2001) find strong interlinkages among Central and Eastern Europe stock exchange. On the other hand, Vizek and Dadic (2006) examine the integration between German equity markets and selected Central and Eastern European stock markets with the Croatian equity market. Interestingly, the author did not find any evidence of a long-term relationship between the Croatian and German stock markets. A similar conclusion is drawn for the Central European stock markets with respect to the German stock market. At the same time Babetskii, Komarek, and Komarkova (2007) take a different methodological perspective to assess stock market integration. They calculate the rolling bconvergence and s-convergence to evaluate the interdependence of Central European and Western European stock markets. ${ }^{1}$

A study with high frequency data was undertaken by Egert and Kocenda (2007); the authors analyze the interconnections between Western European stock markets and stock markets in the Czech Republic, Hungary, and Poland. Using Granger causality tests based on 5-min tick intra day data from mid-2003 to early 2005, they do not find any robust cointegration relationship between Central European and Western European stock markets. In a similar vein, Kocenda and Egert (2011) study ultra-high frequency data for three developed (France, Germany, and Britain) and three emerging (CzechRepublic,Hungary, and Poland) European stock markets and find weak correlations between these developed and emerging markets during the trading day. The authors conclude that the transmission of shocks among these markets materializes more at daily or even weekly frequency, rather than at tick by-tick data frequency. Egert and Kocenda (2007) analyze the co-movements among stock markets in Central and Eastern Europe using 5-min intraday price data spanning from mid- 2003 to early 2005 for stock indices, using cointegration relationships. The study observed signs of short-term spillover effects both in terms of stock returns and stock price volatility and identified a number of short term relationships among the stock markets.

Horvath and Petrovski (2013) examine the international stock market comovements between Western Europe, Central, and South Eastern Europe using multivariate GARCH models. The study found a high degree of co-movements for Central Europe that are not correlated with South Eastern European stock markets. Moreover, all stock markets are observed to fall strongly at the beginning of the global financial crisis and we do not find any evidence that the crisis altered the degree of stock market integration among these groups of countries. Onay (2006) examines the long-term financial integration of second-round accessions and candidate countries with the European Union and the U.S. stock markets during the Accession Process and indicates that the completion of accession negotiations with Bulgaria and Romania and the ongoing negotiations with Croatia and Turkey did not result in the complete financial integration of these markets with the European Union.

The existing research therefore provides some what mixed results. Some papers fail to find any long-term relationship between stock markets, whereas some found valid evidence for this.

Nevertheless, it seems that the majority of papers confirm the evidence of interlinkages among the stock markets in the short term as well as in the long run. 


\section{Nature and sources of data}

The present study uses benchmark indices of the countries as representatives of their respective stock markets. We take weekly index series and the data period spans from the $2^{\text {nd }}$ week of August 1995 to the 4th week of December 2013, across the 17 countries' stock markets and the world market (MSCI). Log transformation of the indices has been undertaken to make the series smooth. The indices are collected from sources subscribing to Bloomberg. The descriptions of the country benchmark indices are presented in Appendix.

\section{Methods}

To capture the short term dynamics of the return distribution, and the long run equilibrium relationship between the stock markets, the present study uses various time series techniques. The time series properties of the sample of 18 stock markets, including the world index MSCI, are tested in various ways. To trace out the short term dynamic relationships and to identify the interlinkages and the long run equilibrium relationships between the stock markets, this study uses the variance decomposition techniques of the VAR model, the vector error correction model (VECM), and the Johansen maximum likelihood test statistic. Before estimating the models, the unit root properties of the country benchmark indices including MSCI are tested by using DF, $\mathrm{ADF}$, and PP techniques, as detailed below.

\section{Tools of time series analysis}

In the time series literature, there are both parametric and non-parametric tests for stationarity. The informal tests include time series plots and the use of correlograms. Statistical packages use Box-Pierce Q-statistics and L-jung-Box Q-statistics to test the stationarity of series. These two statistics are based on auto correlation coefficients of several lag lengths. The formal tests of non-stationarity known as the unit root test or test of random walk series are undertaken through Dickey-Fuller (DF), augmented Dickey-Fuller (ADF), and Phillips-Perron (PP) tests. These tests are necessary, because the usual Student's $t$-test is inappropriate to test the null hypothesis $\beta=1$. DF and ADF tests are based on the assumption that the error terms are uncorrelated or are independently and identically distributed $\left(0, \sigma^{2}\right)$ Gaussian processes. Again, the ADF test adjusts the DF test to take care of possible serial correlations in the error terms by adding the lagged difference terms of the regressand. On the other hand, the PP test is a non-parametric statistical method that takes care of serial correlations in the error terms. Another advantage of the PP test is that it can also be applied to the frequency domain approach, which is a more recent alternative to the usual time domain approach to time series analysis.

\section{Vector autoregression (VAR) model}

In a single equation time series framework, it is possible to study the effect of a shock-contemporaneous or time dependent-in an exogenous variable, using intervention or transfer function analysis, respectively. Sometimes the relationship between variables in a dynamic system cannot be represented in a single equation time series model. Further, when we are not confident that a variable is truly exogenous, a natural 
extension of transfer function analysis is to treat each variable symmetrically. This can be explained with the help of a simple example. Following Enders (1995), let the time path of the stock market return of country $\mathrm{x}$ at time $\mathrm{t}\left(\mathrm{x}_{\mathrm{t}}\right)$ be affected linearly by the current and past realizations of stock market return of country $y$ at time $t\left(y_{t}\right)$ and vice versa. This implies the following simple bivariate system between these variables:

$$
\begin{aligned}
& x_{t}=b_{10}-b_{12} y_{t}+\alpha_{11} x_{t-1}+\alpha_{12} y_{t-1}+\varepsilon_{x t} \\
& y_{t}=b_{20}-b_{21} x_{t}+\alpha_{21} x_{t-1}+\alpha_{22} y_{t-1}+\varepsilon_{y t}
\end{aligned}
$$

It is assumed that both xt and yt are stationary and that the error terms, $\varepsilon_{x t}$ and $\varepsilon_{y t}$ satisfy the OLS assumptions (white noise properties). The above two Eqs. (1) and (2) constitute a first order vector autoregression (VAR), because the longest lag length is unity. Such a system is also known as a "structural" or"primitive" VAR model. This simple two variable first-order VAR is useful for illustrative purposes and can be generalized to a multivariate higher-order system. Here the structure of the model incorporates feedback effects, since $\left(x_{t}\right)$ and $\left(y_{t}\right)$ are allowed to affect each other. Hence $\varepsilon_{x t}$ has an indirect contemporaneous effect on yt and $\varepsilon_{y t}$ has an indirect contemporaneous effect on $\mathrm{x}_{t}$ due to the feedback inherent in the system. The reduced form of the above system can be written as:

$$
\begin{aligned}
& x_{t}=a_{10}+a_{11} x_{t-1}+a_{12} y_{t-1}+e_{x t} \\
& y_{t}=a_{20}+a_{21} x_{t-1}+a_{22} y_{t-1}+e_{y t} . \\
& \quad a_{10}=\frac{b_{10}-b_{12} b_{20}}{1-b_{12} b_{21}} \cdot \quad a_{11}=\frac{\alpha_{11}-b_{12} \alpha_{21}}{1-b_{12} b_{21}} \cdot \quad a_{12}=\frac{\alpha_{12}-b_{12} \alpha_{22}}{1-b_{12} b_{21}}
\end{aligned}
$$

Where

$$
\begin{aligned}
& a_{20}=\frac{b_{20}-b_{21} b_{10}}{1-b_{21} b_{12}} \cdot \quad a_{21}=\frac{\alpha_{21}-b_{21} \alpha_{11}}{1-b_{21} b_{12}} \cdot \quad a_{22}=\frac{\alpha_{22}-b_{21} \alpha_{12}}{1-b_{21} b_{12}} \\
& e_{c t}=\frac{\varepsilon_{c t}-b_{12} \varepsilon_{y t}}{1-b_{12} b_{21}} \quad \text { and } \quad e_{y t}=\frac{\varepsilon_{y t}-b_{21} \varepsilon_{c t}}{1-b_{21} b_{12}}
\end{aligned}
$$

In contrast to the system in Eqs. (1) and (2), the reduced form model in Eqs. (3) and (4) is called the "standard" VAR or simply the VAR model. Since $\varepsilon_{x t}$ and $\varepsilon_{y t}$ are white-noise processes, it follows that $e_{x t}$ and $e_{y t}$ have zero mean and constant variance, and are individually serially uncorrelated. In a VAR framework, innovation accounting techniques like impulse responses and variance decomposition are more informative. The variance decomposition splits the variation in an endogenous variable in to the component shocks to the endogenous variables in the VAR system. This gives information about the relative importance of each random fluctuation in the system.

\section{Choice of Lag length}

Selection of lag length for the VAR model is the next important step. In principle, it is possible to have different lag lengths for different variables both within and across equations. If there are good reasons to do this, one can specify and estimate such a model, called the "near" VAR. The seemingly unrelated regression estimation (SURE) method can be used to get efficient VAR estimates. On the other hand, if all the 
variables in the VAR model have the same lag length, then the model will be symmetric and can be estimated using the ordinary least square (OLS) method. The OLS estimators will then be consistent and asymptotically efficient. Further, in a VAR model, fewer lags are preferred, because higher lag length for any variable implies more parameters to be estimated and fewer degrees of freedom. Thus, it will be convenient to use the same optimal lag length for all equations. There are various alternative criteria that can be used for selecting the optimal lag length. Hsiao (1981) develops a systematic autoregressive method for choosing appropriate lag length. According to him, the appropriate lag length is the one for which Akaike's final prediction error (FPE) is lowest. Other criteria such as the Akaike information criterion (AIC), Schwarz criterion (SC), likelihood ratio (LR) criterion, and Hannan-Quinn information criterion (HQ) are also useful in choosing the lag length. ${ }^{2}$

\section{The cointegration test}

The long run equilibrium relationship between the variables can be detected through cointegration techniques. The study of cointegration uses two methods, namely Engel and Granger (1987) and the Johansen (1988) maximum likelihood procedure. Though the present study undertakes multivariate analysis, it uses the Johansen maximum likelihood procedure to identify the long run equilibrium relationships among the variables, as discussed below.

\section{Johansen maximum likelihood and vector error correction model}

The Johansen test for cointegration begins by considering the unrestricted reduced form of a system of variables, which by assumption can be represented as a finite order VAR model:

$$
x_{t}=A_{1} x_{t-1}+A_{2} x_{t-2}+\ldots+A_{p} x_{t-p}+\varepsilon_{t}
$$

where, $x_{t}=\left(x_{1 t}, x_{2 t}, \ldots, x_{n t}\right)$, an $(n \times 1)$ vector;

$A_{i}=(n \times n)$ is the matrix of parameters; and

$\varepsilon_{t}=$ is an independently and identically distributed $n$-dimensional vector with mean 0 and variance $\Sigma_{\varepsilon}$

Equation (5) can be reformulated as follows:

$$
\Delta x_{t}=\sum^{p-1} \prod_{i} \Delta x_{t-i}+\prod x_{t-p}+\varepsilon_{t} i=1
$$

where, $\Pi=-\left[I-\sum_{i=1}^{p} A_{i}\right]$

$$
\begin{gathered}
\prod_{i}=-\left[I-\sum_{j=1}^{i} A_{j}\right] \\
\mathrm{I}=(\mathrm{n} \times \mathrm{n}) \text { identity matrix }
\end{gathered}
$$

Equation (6) contains information on both the short run and long run adjustment to changes in $x_{t}$ via the estimates of $\Pi_{i}$ and $\Pi$ respectively. $\Pi x_{t-p}$ in Eq. (6) is the error correction factor. In order to test restrictions on the cointegrating vector, Johansen (1988) defines the two matrices $\alpha$ and $\beta$, both of dimensions $(n \times r)$, where $r$ is the rank of $\Pi$. The 
properties of $\alpha$ and $\beta$ are such that $\Pi=\alpha \beta$. Hence Eq. (6) can be rewritten as: $\Delta x_{t}$ $=\sum \prod_{i=1^{p-1}} \Delta x i_{t-i}+\alpha \beta^{\prime} x_{t-p}+\varepsilon_{t}$. The matrix $\beta$ is the matrix of cointegrating parameters and the matrix $\alpha$ is the matrix of weights, with each cointegrating vector entering the $n$ equations of the VAR. In a sense, $\alpha$ can be viewed as the matrix of the speed of adjustment parameter. Due to the cross equation restrictions, it is not possible to estimate $\alpha$ and $\beta$ using OLS. However, with maximum likelihood estimates, it is possible to estimate Eq. (6) as an error correction model, determine the rank of $\Pi$ and use the $r$ most significant cointegrating vectors to form $\beta^{\prime}$. In Eq. (6), the rank of $\Pi$ is equal to the number of independent cointegrating vectors. If rank $(\Pi)=0$, the matrix is null, and there is no cointegration among the set of $\mathrm{n}$ variables. It means there is no linear combination of variables that is stationary. Hence, Eq. (6) will become a usual VAR model in first differences. If $\operatorname{rank}(\Pi)=\mathrm{n}$, the vector process is stationary; and if rank $(\Pi)=1$, there is a single cointegrating vector and the term $\Pi x_{t^{-} p}$ is the error correction factor. For the other cases in which $1<\operatorname{rank}(\Pi)<\mathrm{n}$, there are multiple cointegrating vectors.

The number of distinct cointegrating vectors can be obtained by checking the significance of the characteristic roots of $\Pi$. The number of cointegrating vectors is equal to the rank of the matrix $\Pi$ and the rank of this matrix is equal to the number of characteristic roots that are different from zero. The Johansen methodology allows us to determine the number of characteristic roots that are statistically different from zero. If the variables in $x_{t}$ are not cointegrated, the rank of $\Pi$ is zero and all the characteristic roots $\left(\lambda_{i}\right)$ will be equal to zero. In practice, we can obtain only estimates of $\Pi$ and the characteristic roots. The test for the number of characteristic roots that are significantly different from unity can be conducted using the following two test statistics:

$$
\begin{aligned}
& \lambda_{\text {trace }}(r)=-T \sum_{i=r+1}^{n} \ln \left(1-\hat{\lambda}_{i}\right) \\
& \lambda_{\max }(r, r+1)=-T \ln \left(1-\hat{\lambda}_{r+1}\right)
\end{aligned}
$$

where, $\hat{\lambda}_{i}=$ estimated value of characteristic root obtained from the estimated $\Pi$ matrix $\mathrm{T}=$ no. of usable observation

$r=$ no. of cointegrating vectors

When the appropriate values of $\mathrm{r}$ are clear, these statistics are simply referred to as $\lambda_{\text {trace }}$ and $\lambda_{\max }$. The first test statistic tests that the number of distinct cointegrating vectors is less than or equal to $\mathrm{r}$ against a general alternative. Thus, $\lambda_{\text {trace }}=0$ when all $\lambda_{i}=0$. The second test statistic tests the hypothesis that the number of cointegrating vectors is $r$ against the alternative of $(r+1)$ cointegrating vectors. Johansen and Juselius (1990) provide the critical values of $\lambda_{\text {trace }}$ and $\lambda_{\max }$ statistics. The estimated values of the above two statistics are compared with the Johansen and Juselius critical value to determine the number of cointegrating vectors that exist among the variables. This procedure allows for the testing of restricted forms of the cointegrating vectors. Restrictions can be imposed on the cointegrating vectors or on adjustment coefficients, and we can accordingly conclude whether restrictions are binding or not by using the statistic proposed by Johansen. 
If the test statistics indicate that one cointegrating vector exists, maximum likelihood estimates of this vector are given by the first column of $\beta$. Hence, the VECM representation, which is equivalent to Eq. (6), is given by:

$$
\Delta x_{t}=\sum_{i=1}^{p-1} \prod_{i} \Delta x_{t-i}+\alpha e c m_{t-1}+\varepsilon_{t}
$$

where, $e c m_{t-1}=\beta x_{t-1}$

$$
\beta=\left[\beta_{1} \ldots \ldots \beta_{n}\right]
$$

Again, if tests indicate that two cointegrating vectors exist, then the first two columns of $\beta$ provide the maximum likelihood estimates of these vectors and the VECM is given by:

$$
\Delta x_{t}=\sum_{i=1}^{p-1} \prod_{i} \Delta x_{t-i}+\alpha_{1} e c m_{1 t-1}+\alpha_{2} e c m_{2 t-1}+\varepsilon_{t}
$$

Here, $\alpha_{1}$ and $\alpha_{2}$ represent the effects of the stationary linear combination of $e c m_{1}$ and $e \mathrm{~cm}_{2}$ on the system, and are otherwise called the speed of adjustment parameters. The VECM approach can be used to test Granger causality among the vectors of variables, by testing the statistical significance of the adjustment coefficients and the coefficients of the lagged explanatory variables.

\section{Results and Discussions}

To trace out the dynamic interlinkages between the stock markets, this study uses the variance decomposition techniques of the VAR model. The long run equilibrium relationships and correction of short run error has been estimated through Johansen maximum likelihood estimation techniques. The time series properties of these indices are studied under different heads as presented below. The unit root properties of the benchmark indices are presented in Tables 1 and 2, which contain the estimated $\tau$-statistic values at level and first difference respectively. It is observed that indices contain unit root at level and become stationary at first difference.

\section{Decomposition of forecast error variance of the return distribution}

The optimum lag length of 2 for the VAR model has been identified by using five lag selection criteria, comprising the LR, FPE, SC, AFC, and HQ models. The results of variance decomposition are presented in Table 3. As explained in the Methods section, the forecast error variance of each stock market of the region is allocated to provide the component of forecast error variance that is for by innovations in each of the seventeen stock markets. Table 3 provides the decomposition of forecast error variance of 1, 2, 5, and 10 week ahead forecasts of stock market returns into frictions that are accounted for by fluctuations in different markets. Table 3 explains the inputs that identify the main channels of influence in the seventeen stock market-based dynamical system. It is noted from the estimated decomposition of forecast variance of the VAR system that stock markets in Austria, Belgium, France, and the Netherlands appear as exogenous in the sense that these markets explain almost $90 \%$ of their own fluctuations, leaving 
Table 1 The estimated $\tau$-statistic values from unit root tests (Level)

\begin{tabular}{llllllll}
\hline \multirow{2}{*}{ Variable } & \multicolumn{2}{l}{ Intercept Alone } & & & \multicolumn{1}{l}{ Intercept + Trend } \\
\cline { 2 - 3 } & DF & ADF & PP & & DF & ADF & PP \\
\hline Austria & 1.742 & $1.98(2)$ & $1.58(1)$ & & -0.290 & $-1.53(2)$ & $-1.19(3)$ \\
Belgium & -0.91 & $-0.91(2)$ & $-0.87(1)$ & & -0.89 & $-0.98(2)$ & $-0.86(1)$ \\
Britain & -2.01 & $-1.98(2)$ & $-1.83(1)$ & & -2.06 & $-1.99(2)$ & $-1.78(1)$ \\
Denmark & -1.63 & $-1.72(2)$ & $-1.65(2)$ & & -1.63 & $-1.83(2)$ & $-1.67(2)$ \\
Finland & -0.66 & $-0.91(3)$ & $-0.66(4)$ & & -0.76 & $-1.01(3)$ & $-0.54(3)$ \\
France & -1.73 & $-1.54(1)$ & $-1.33(3)$ & & -1.88 & $-1.54(1)$ & $-1.25(1)$ \\
Germany & -2.04 & $-1.93(2)$ & $-1.95(2)$ & & -2.18 & $-1.87(2)$ & $-1.91(2)$ \\
Greece & -1.75 & $-1.47(2)$ & $-1.99(4)$ & & -1.89 & $-1.56(2)$ & $-1.35(4)$ \\
Ireland & -1.77 & $-1.56(1)$ & $-1.99(5)$ & & -1.76 & $-1.83(1)$ & $-1.89(5)$ \\
Italy & -2.14 & $-2.75(2)$ & $-2.76(4)$ & & -2.17 & $-2.86(2)$ & $-2.75(4)$ \\
Luxembourg & 0.34 & $-1.01(4)$ & $-0.69(5)$ & & -0.85 & $-0.89(3)$ & $-0.83(5)$ \\
Netherlands & -1.85 & $-2.27(3)$ & $-2.85(2)$ & & -1.18 & $-2.38(2)$ & $-2.72(2)$ \\
Norway & -0.67 & $-1.39(2)$ & $-1.72(4)$ & & -0.83 & $-1.39(3)$ & $-1.37(4)$ \\
Portugal & -1.78 & $-2.56(3)$ & $-1.88(4)$ & -1.59 & $-2.87(3)$ & $-1.43(4)$ \\
Spain & -1.78 & $-1.82(3)$ & $-1.65(4)$ & -1.69 & $-1.85(4)$ & $-1.87(4)$ \\
Sweden & -1.64 & $-1.66(2)$ & $-1.73(5)$ & -1.55 & $-1.66(2)$ & $-1.68(5)$ \\
Switzerland & -1.78 & $-2.67(2)$ & $-1.23(2)$ & -1.11 & $-2.78(2)$ & $-1.67(2)$ \\
MSCl & -1.42 & $-1.5(2)$ & $-1.6(4)$ & -1.42 & $-1.6(2)$ & $-1.5(4)$ \\
\hline
\end{tabular}

Table 2 The estimated $\tau$-statistic values from unit root tests (First Difference)

\begin{tabular}{|c|c|c|c|c|c|c|}
\hline \multirow[t]{2}{*}{ Variable } & \multicolumn{3}{|c|}{ Intercept alone } & \multicolumn{3}{|c|}{ Intercept + Trend } \\
\hline & $\mathrm{DF}$ & ADF & $\mathrm{PP}$ & $\mathrm{DF}$ & ADF & PP \\
\hline Austria & $-23.2^{*}$ & $-19.2^{*}(1)$ & $-25.1^{*}(1)$ & $-23.2^{*}$ & $-19.9 *(1)$ & $-25.2^{*}(1)$ \\
\hline Belgium & $-23.5^{*}$ & $-17.75^{*}(1)$ & $-23.44^{*}(1)$ & $-23.43^{*}$ & $-17.5^{*}(1)$ & $-24.4^{*}(1)$ \\
\hline Britain & $-25.8^{*}$ & $-18.76^{*}(1)$ & $-26.76^{*}(1)$ & $-24.89^{*}$ & $-18.3^{*}(1)$ & $-26.8^{*}(1)$ \\
\hline Denmark & $-24.7^{*}$ & $-17.63^{*}(1)$ & $-25.11 *(1)$ & $-25.13^{*}$ & $-17.6^{*}(1)$ & $-25.6^{*}(1)$ \\
\hline Finland & $-25.1^{*}$ & $-26.8^{*}(1)$ & $-28.77^{*}(1)$ & $-25.45^{*}$ & $-26.8^{*}(1)$ & $-28.5^{*}(1)$ \\
\hline France & $-24.6^{*}$ & $-17.53^{*}(1)$ & $-26.81^{*}(1)$ & $-24.6^{*}$ & $-17.5^{*}(1)$ & $-26.7^{*}(1)$ \\
\hline Germany & $-22.6^{*}$ & $-17.8^{*}(1)$ & $-23.6^{*}(1)$ & $-22.7^{*}$ & $-17.3^{*}(1)$ & $-23.5^{*}(1)$ \\
\hline Greece & $-24.4^{*}$ & $-19.1 *(1)$ & $-24.4^{*}(1)$ & $-24.39^{*}$ & $-19.0^{*}(1)$ & $-24.3^{*}(1)$ \\
\hline Ireland & $-24.3^{*}$ & $-17.8^{*}(1)$ & $-24.5^{*}(1)$ & $-24.4^{*}$ & $-17.9^{*}(1)$ & $-24.4^{*}(1)$ \\
\hline Italy & $-20.2^{*}$ & $-14.3^{*}(1)$ & $-19.87^{*}(1)$ & $-20.30^{*}$ & $-14.4^{*}(1)$ & $-19.3^{*}(1)$ \\
\hline Luxembourg & $-21.9^{*}$ & $-15.5^{*}(1)$ & $-22.4^{*}(1)$ & $-22.51^{*}$ & $-15.7^{*}(1)$ & $-23.5^{*}(1)$ \\
\hline Netherlands & $-24.5^{*}$ & $-19.9^{*}(1)$ & $-25.15^{*}(1)$ & $-24.7^{*}$ & $-19.6^{*}(1)$ & $-25.7^{*}(1)$ \\
\hline Norway & $-23.6^{*}$ & $-15.25^{*}(1)$ & $-23.83^{*}(1)$ & $-23.54^{*}$ & $-15.9^{*}(1)$ & $-23.5^{*}(1)$ \\
\hline Portugal & $-20.7^{*}$ & $-16.6^{*}(1)$ & $-21.71^{*}(1)$ & $-20.72^{*}$ & $-16.8^{*}(1)$ & $-21.2^{*}(1)$ \\
\hline Spain & $-24.6^{*}$ & $-19.17^{*}(1)$ & $-25.68^{*}(1)$ & $-24.68^{*}$ & $-19.1 *(1)$ & $-25.6^{*}(1)$ \\
\hline Sweden & $-26.3^{*}$ & $-20.5(1)$ & $-27.3^{*}(1)$ & $-26.72^{*}$ & $-21.5^{*}(1)$ & $-27.3^{*}(1)$ \\
\hline Switzerland & $-22.8^{*}$ & $-18.4^{*}(1)$ & $-22.8^{*}(1)$ & $-22.8^{*}$ & $-18.7^{*}(1)$ & $-22.8^{*}(1)$ \\
\hline $\mathrm{MSCl}$ & $20.25^{*}$ & $23.12^{*}(1)$ & $21.01 *(1)$ & $20.54^{*}$ & $24.21^{*}(1)$ & $21.47^{*}(1)$ \\
\hline
\end{tabular}

* and ${ }^{* *}$ represents level of significance at $1 \%$ and $5 \%$ level respectively. ( ) represents the optimum level of lag length 


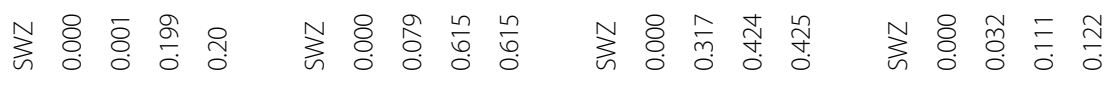

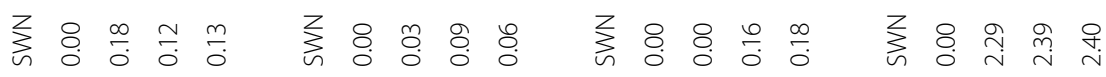

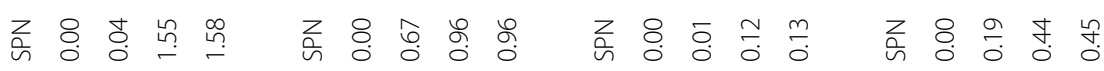

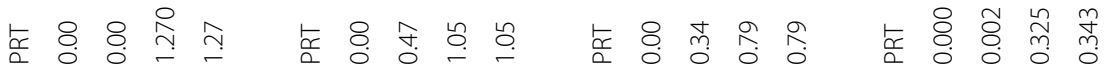

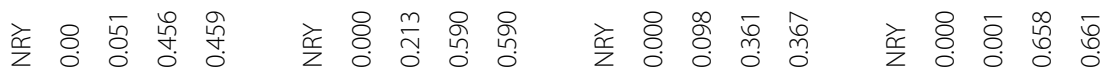

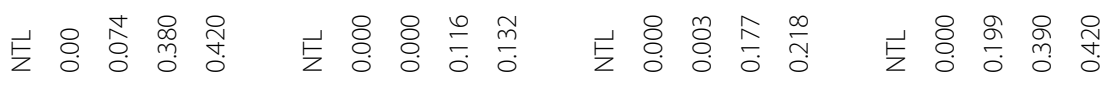

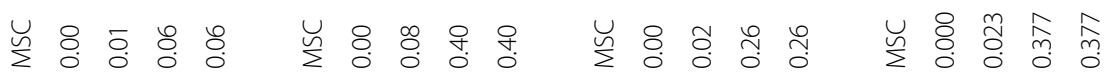

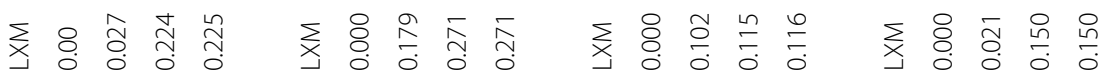

E

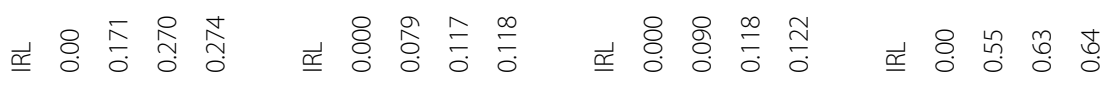

行

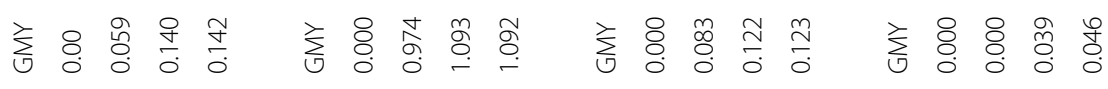

压

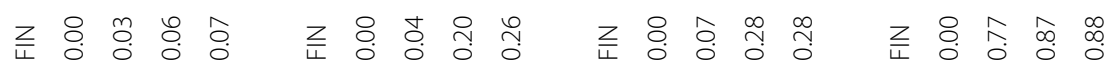

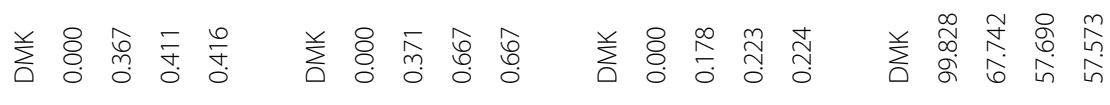

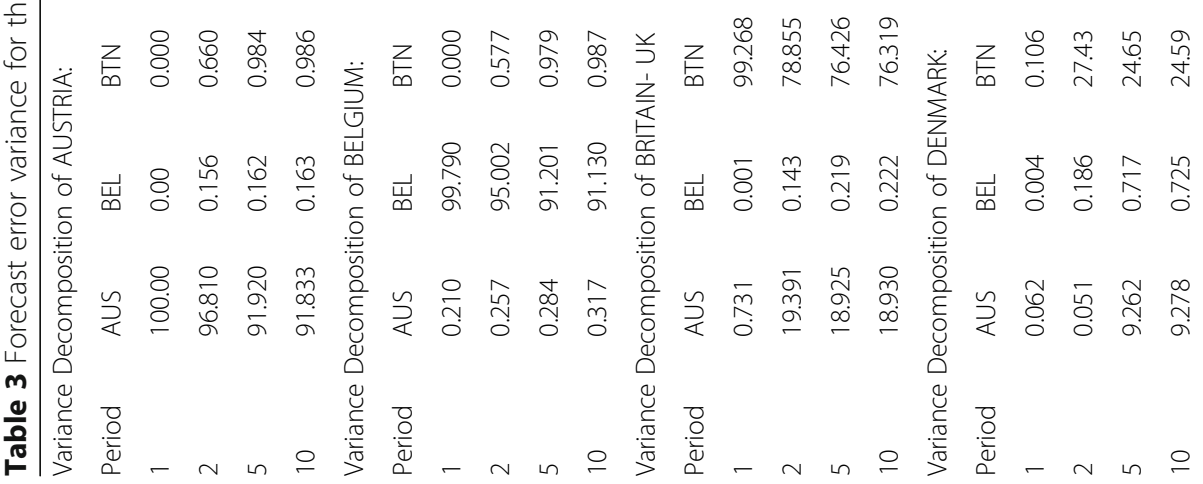




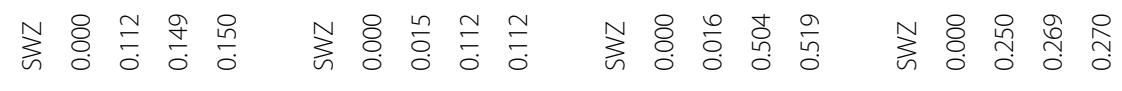

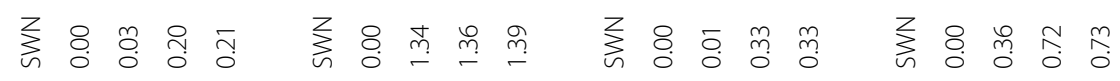

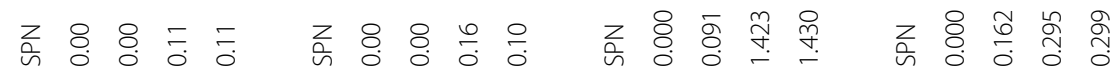

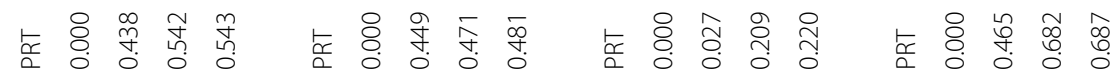
㧡

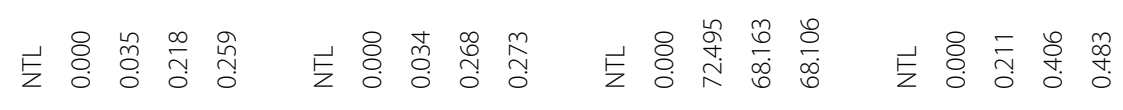

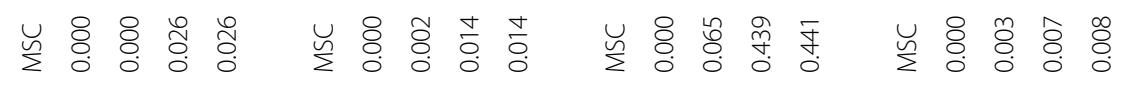

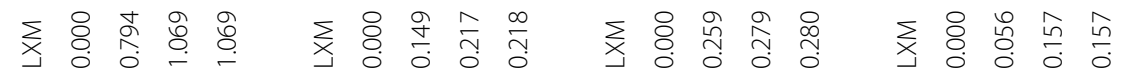

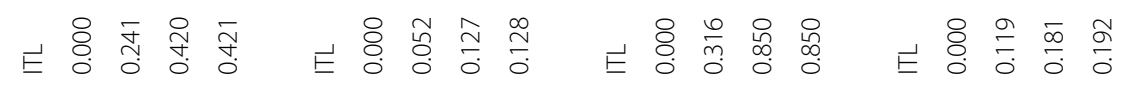
쏘

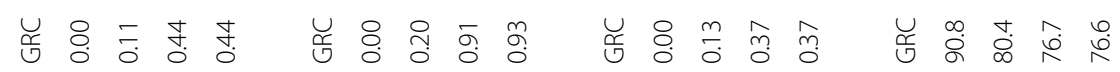

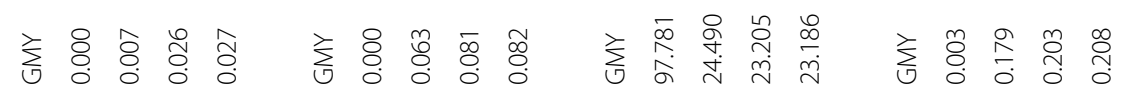
군

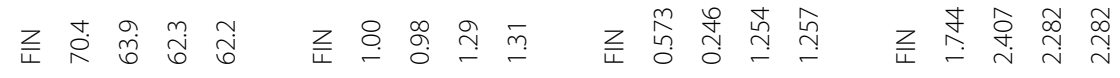

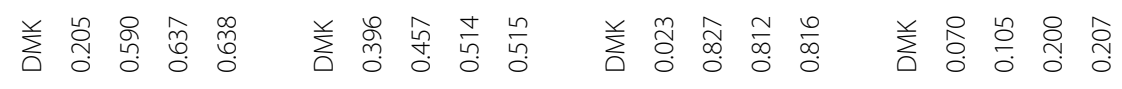

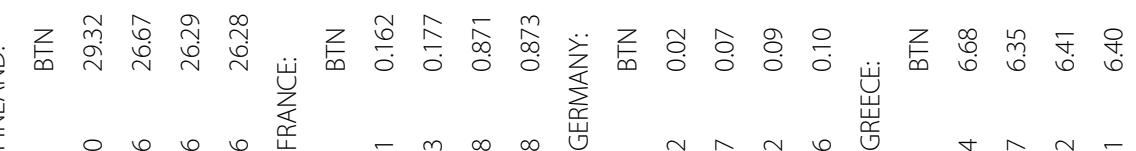

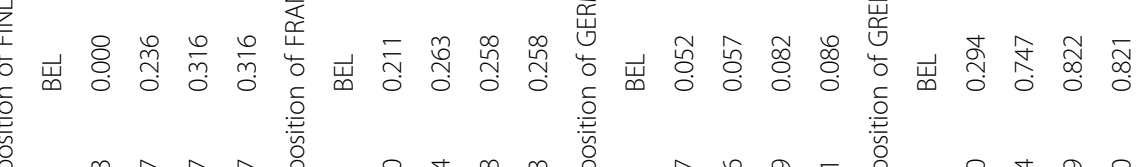

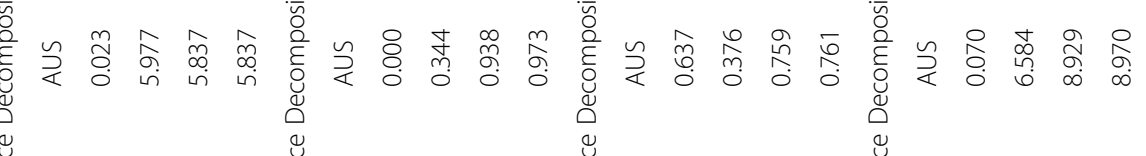

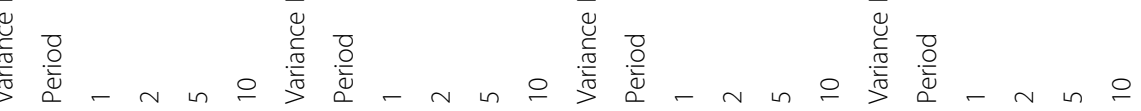




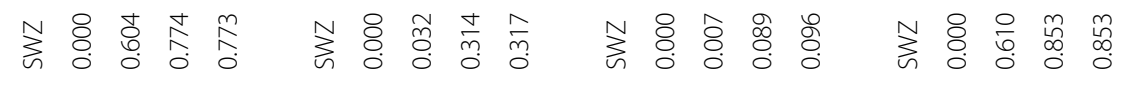

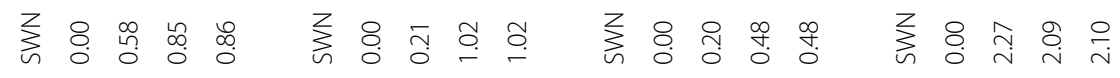

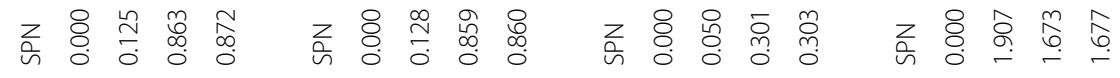
똣

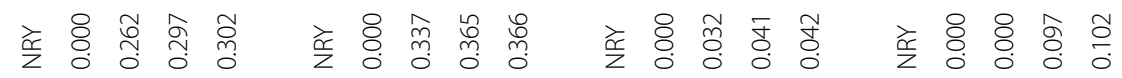

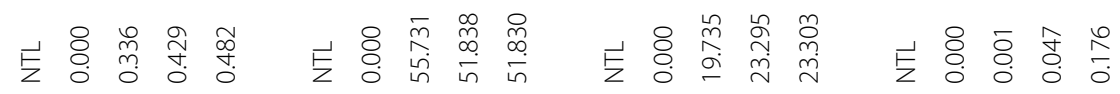

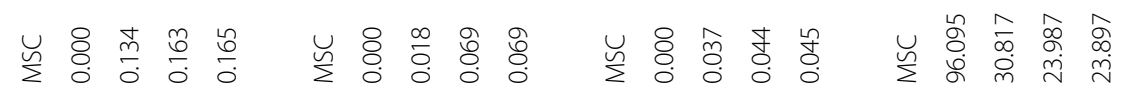

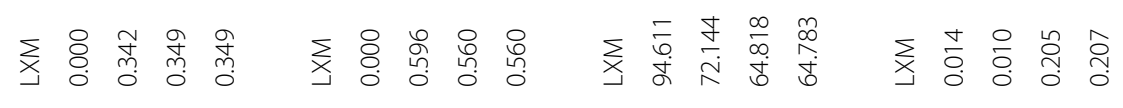
E

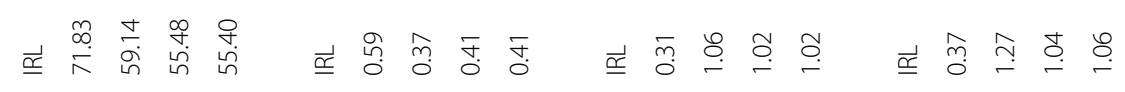

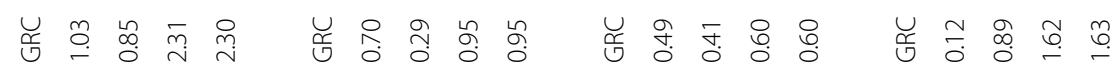

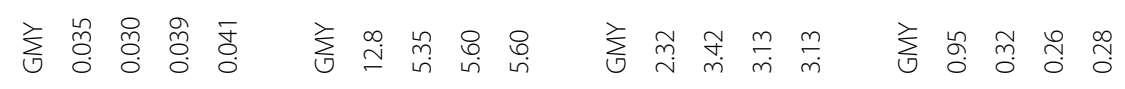

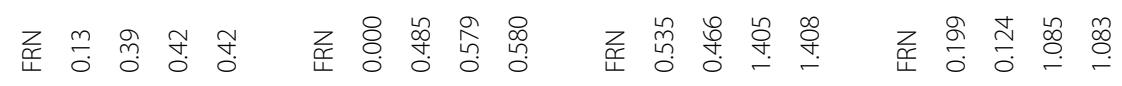

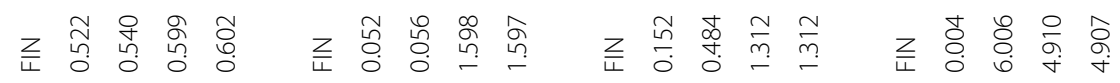

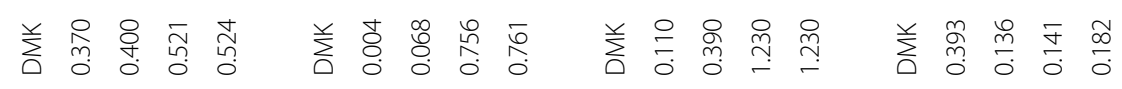

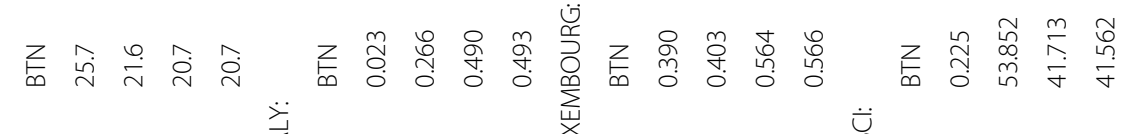

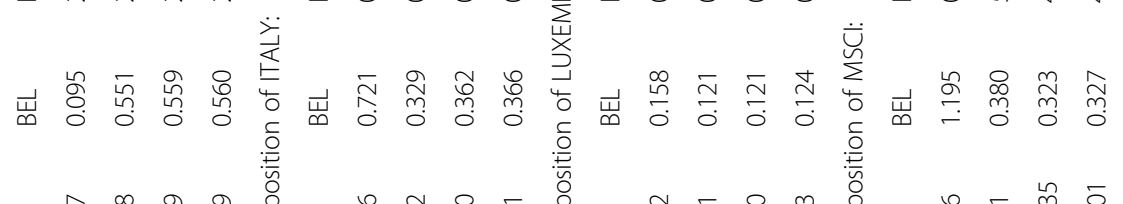

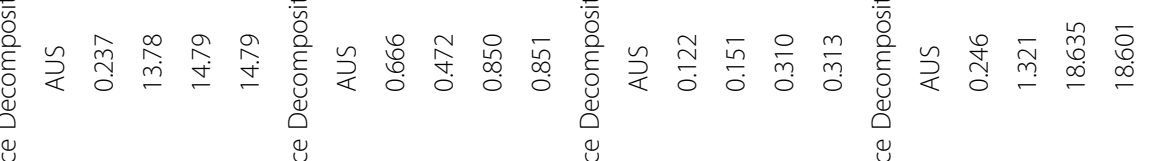

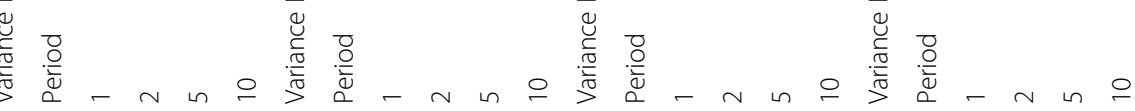




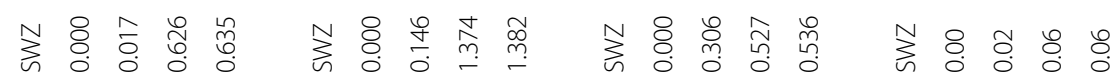

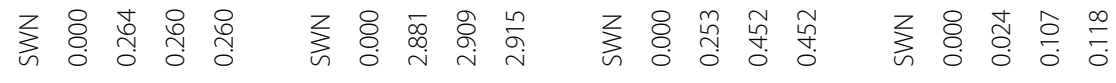

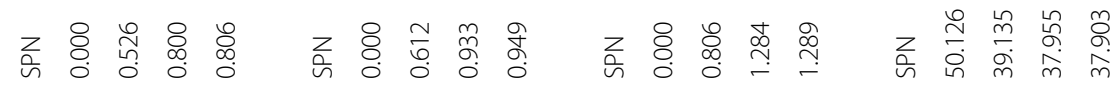

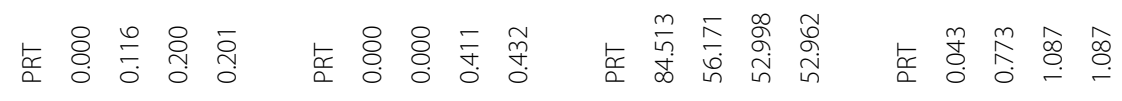

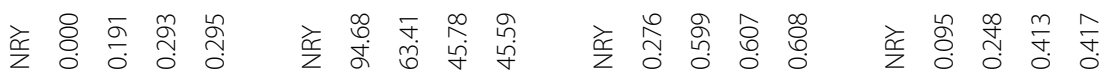

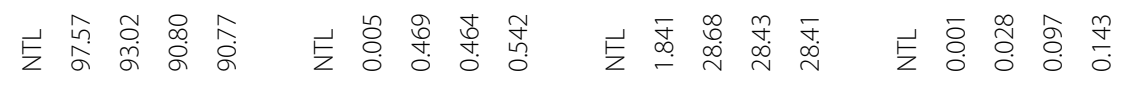

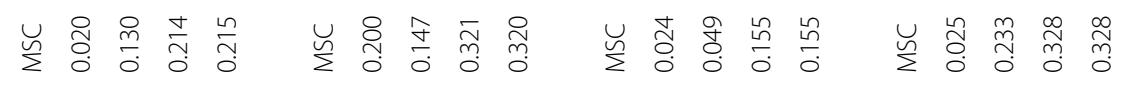

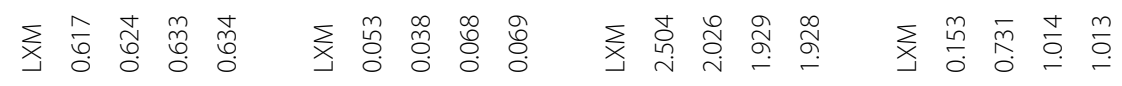

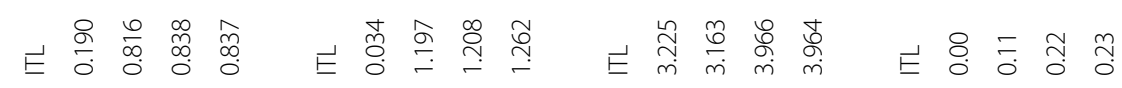

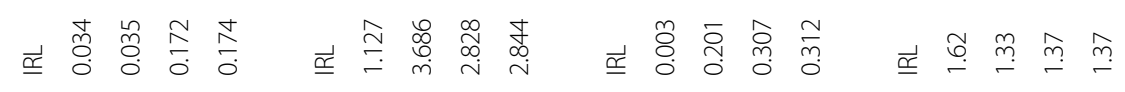

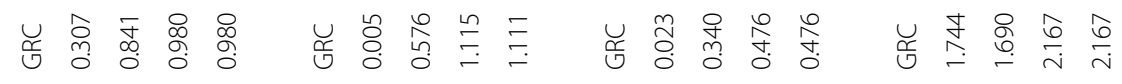

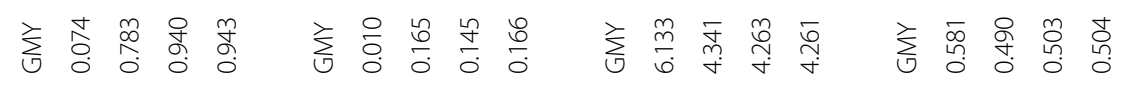

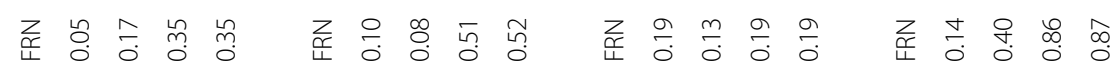

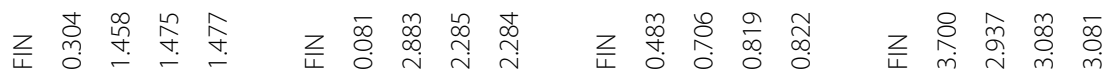

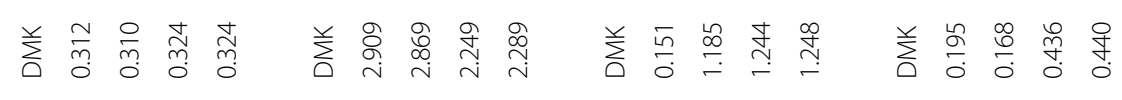

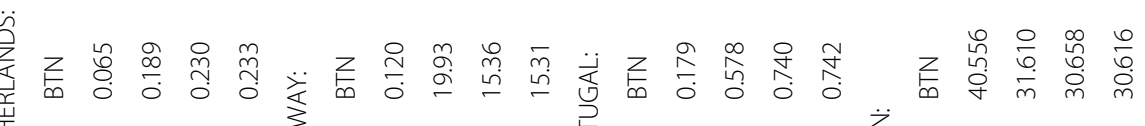

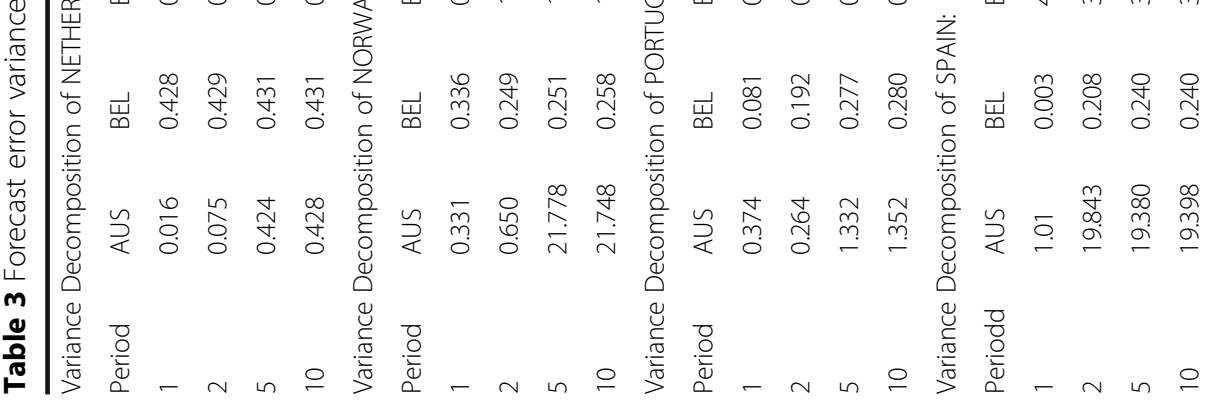




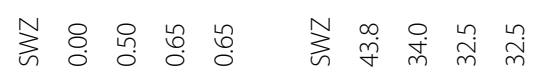

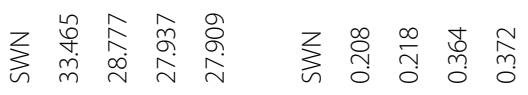

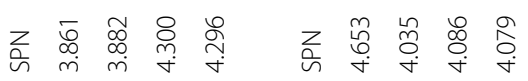

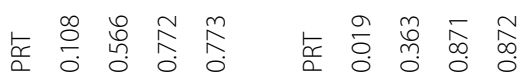

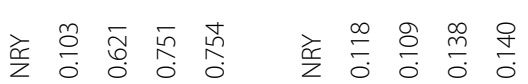

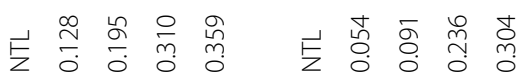

u

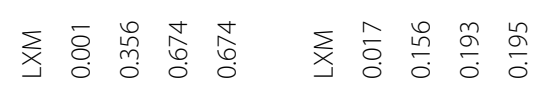

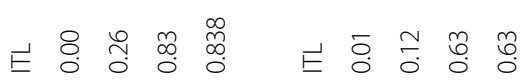

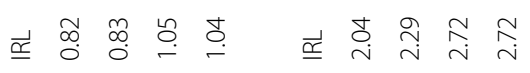

茫

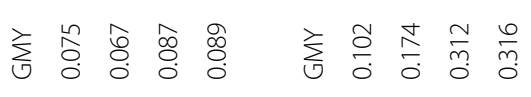

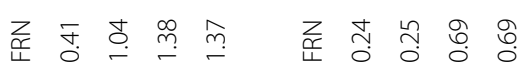

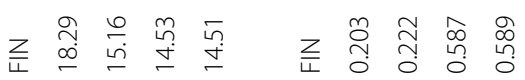

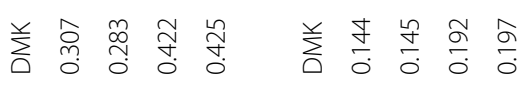

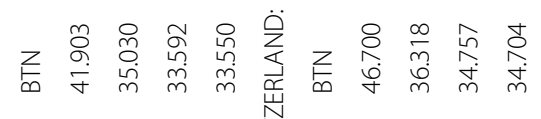

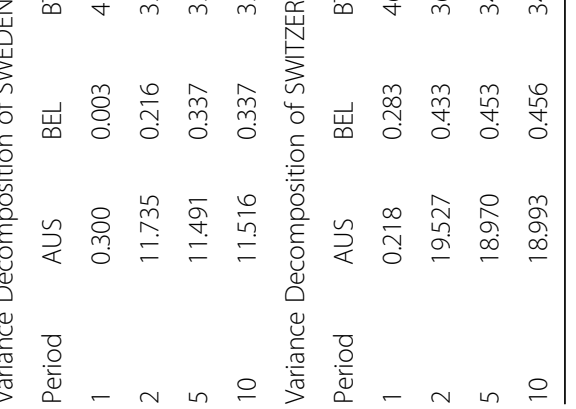


approximately only $10 \%$ to be explained by others. On the contrary, a substantial amount of interaction is effected among the stock markets within the region.

The results in Table 3 provide important information regarding the stock markets, which explains the highest error variance almost in the range of $90 \%$ to $99 \%$ in the 1st to the 10th week period. Austria, Belgium, France, and the Netherlands are, as discussed above, the most influential stock markets in the Western European region. The results give no evidence that any single foreign market can explain more than $2 \%$ of the error variance of all four of these stock markets, while two of these stock markets, i.e., Austria and the Netherlands, explain a significant amount for other stock markets. Austria explains 19\% (for Britain, Spain, and Switzerland), 9\% (for Denmark and Greece), 15\% for Ireland, 22\% for Norway, and 11\% for Sweden, of the foreign market error variance. Similarly, the Netherlands explains $68 \%$ for Germany, 52\% for Italy, 25\% for Luxembourg, and 28\% for Portugal.

Next to Austria, Belgium, France, and the Netherlands, in terms of exogeneity, comes Britain and Greece, which explain almost 70 to $100 \%$ of forecast error variance by themselves.

Beside this, it is evident from the results that Britain is the most interactive stock market in the Western European region. As fluctuations in the British market have significant repercussions in eight other markets, and at the same time, fluctuations in every other market have the scope to affect the British market, the U.K. is identified as having the most interactive stock market.

France is judged to be an independent stock market, as fluctuations in the French market fail to explain any substantial part of the error variances of other markets; and it also provides less scope for other markets to affect its own error variances. On the other hand, there is a horde of stock markets that can be termed as dynamically interlinked in terms of information spillovers. Such stock markets include Denmark, Italy, Ireland, Luxembourg, the Netherlands, Norway, Portugal, Spain, Sweden, and Switzerland.

These stock markets are explained as much by other markets as they explain their own error variances. This means that a free flow of information exists in these stock markets. Any shock in other markets of the same region has an impact on these markets.

MSCI is the global index that has smallest amount of linkages with stock markets all over the world. Thus, the most interlinked stock markets will show comparatively more impact in response to any shocks in the MSCI. In Western Europe, the Netherlands, Norway, Spain, and Switzerland are the particular stock markets that tend to be most affected by a small shock to the MSCI world index. This confirms further that these stock markets are dynamically linked and are influenced by each and every information source world wide. Further, fluctuations in the MSCI fail to have any repercussions on stock markets in countries like Austria, Finland, France, Greece, Italy, Luxembourg, and Sweden. Lastly, stock markets like Belgium, Britain, Denmark, Germany, Ireland, and Portugal are impacted in their 5th and 10th week period after the shock in the MSCI.

\section{Vector error correction model for the return distribution}

The estimated statistics of the VECM model are presented in Table 4. Most of the error correction terms (ECTs) of the stock markets of the region are found to be 


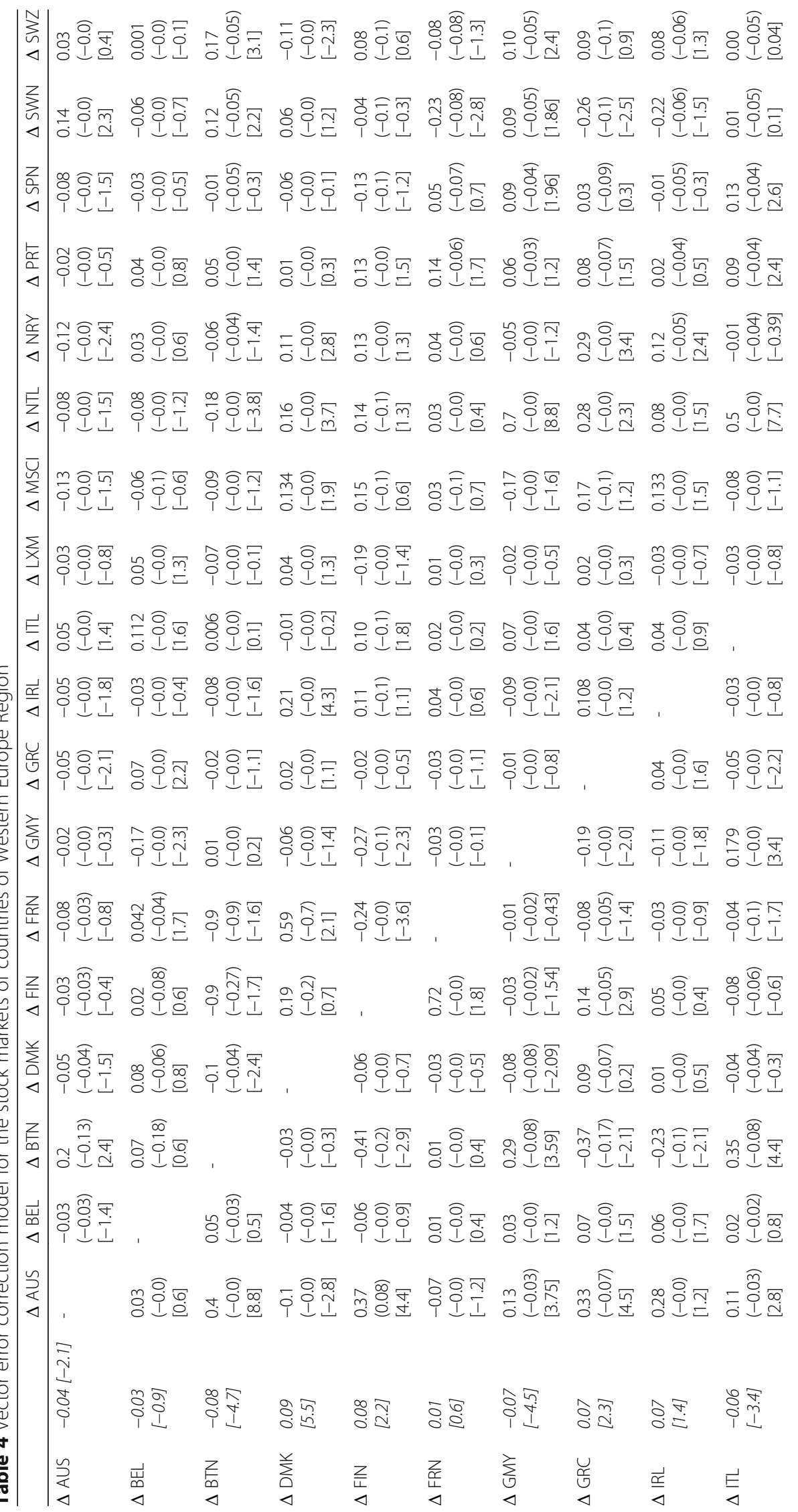




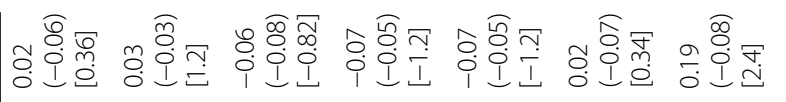

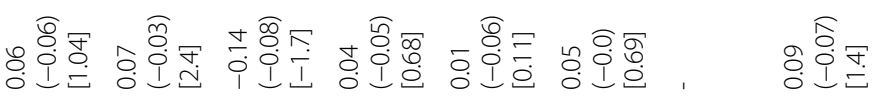

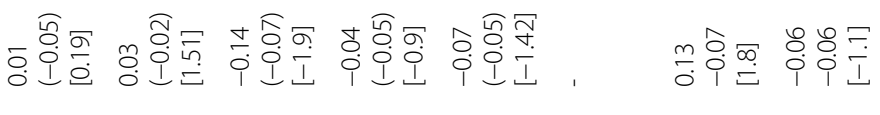

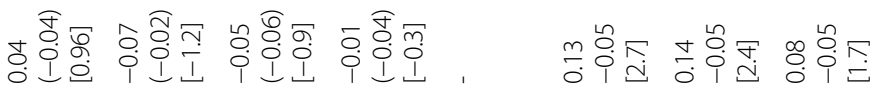

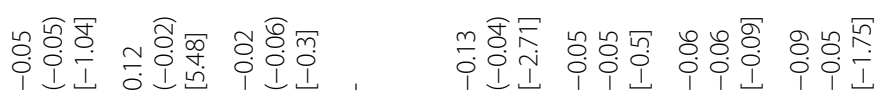

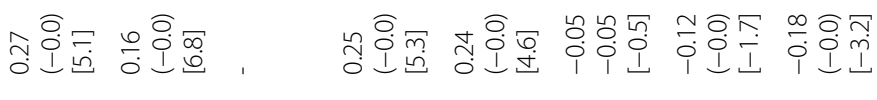

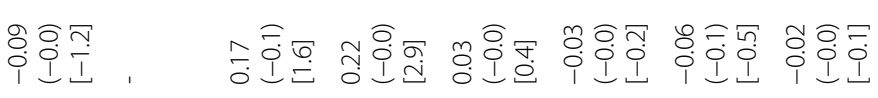

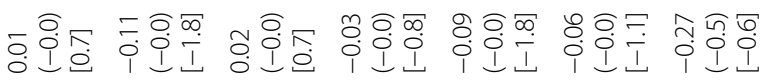

|일

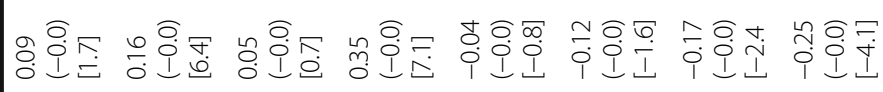

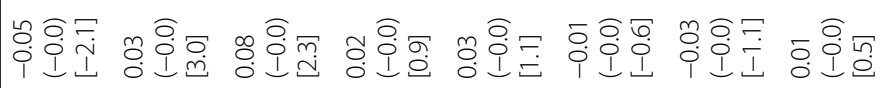

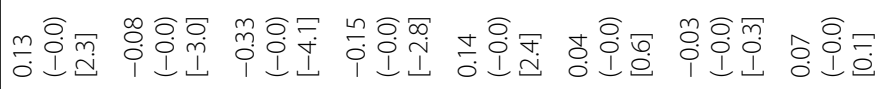

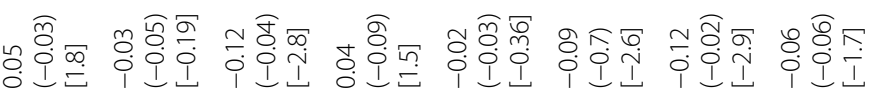

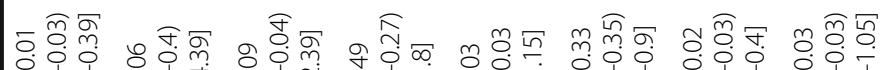

m

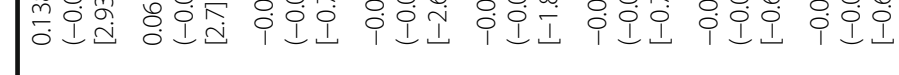

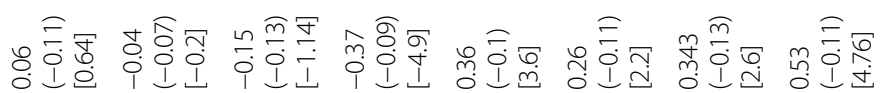

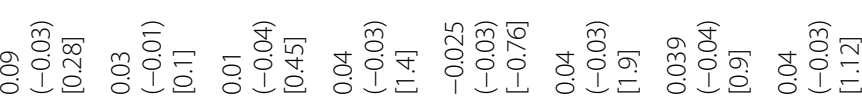

r

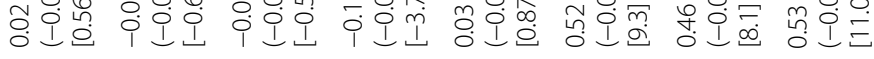

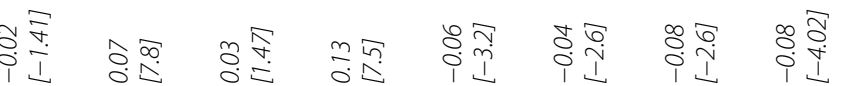

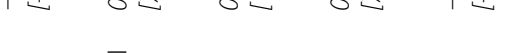

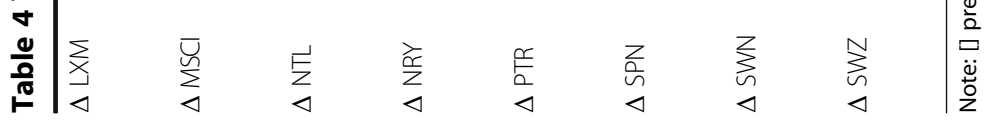


significant, implying that a short term disequilibrium in these stock markets can be corrected significantly by the interactions of the stock markets of this region. The ECTs of the stock markets of Austria, Britain, Denmark, Finland, Germany, Greece, Italy, MSCI, Norway, Portugal, Spain, Sweden, and Switzerland are statistically significant within the region. The significant ECT of Austria is contributed to by the short term lagged differences of the stock markets of Britain, Greece, Norway, and Sweden. The ECT of the British stock market stands in significant relation to the lagged differences of the stock markets of Austria, Denmark, France, Ireland, Netherlands, Sweden, and Switzerland. The ECT of Denmark's stock market is significantly corrected by the short run lagged differences of the stock markets of Austria, France, Ireland, Netherlands, Norway, and Switzerland. In the case of Finland, the lagged independent variables of the stock markets of Austria, Britain, France, and Germany stand to be significant. In the error correction equation of Germany, the short term lagged differences of Austria, Britain, Denmark, Ireland, the Netherlands, and Switzerland are found to be significant. Similarly, for the stock market of Greece, the short term lagged differences of the stock markets of Austria, Britain, Finland, Germany, the Netherlands, Norway, and Sweden are statistically significant. The lagged differences of the stock markets of Austria, Britain, Germany, Greece, the Netherlands, Portugal, and Spain are found to contribute significantly to the ECT of Italy. The ECT of MSCI is significantly due to the significant contributions of Denmark, Finland, Germany, Greece, Ireland, the Netherlands, Norway, and Sweden. In similar fashion, moving to Norway, the significant lagged difference variables are those of Austria, Britain, Denmark, Germany, Ireland, Italy, MSCI, and the Netherlands stock markets. The significant lagged difference of the stock market of Portugal is due to the stock markets of Britain, Germany, the Netherlands, and Norway. The ECT of the stock market of Spain is significantly corrected by the short term lagged differences of the stock markets of Austria, Britain, France, and Portugal. Similarly, the ECT of Sweden's stock market is significantly corrected by the coefficients of stock markets of Austria, Britain, France, Ireland, Portugal, and Switzerland. Lastly, concluding with Switzerland's stock market, its significant ECT is significantly influenced by the stock markets of Austria, Britain, Ireland, and the Netherlands. This shows the existence of short term dynamic interlinkages across most of the national stock markets of Western Europe.

\section{Johansen maximum likelihood test statistics and cointegrating vectors}

The long run equilibrium relationships between the stock markets of Western Europe are tested through the Johansen maximum likelihood technique. The results of Johansen maximum likelihood tests are presented in Table 5 . The $\lambda$-trace statistics suggest two cointegrating vectors at the $1 \%$ probability level and three cointegrating vectors at the $5 \%$ probability level. The null hypotheses of $(r=0)$ and $(r \leq 1)$ are rejected at the 1\% level against the alternative hypotheses of $(r>0)$ and $(r>1)$; and the null hypothesis of $(r \leq 2)$ is rejected at the $5 \%$ level against the alternative hypothesis of $(r>2)$. At the same time, $\lambda$ maximum eigen value statistics suggest only one cointegrating vector at the $1 \%$ probability level and two at the $5 \%$ level. 
Table 5 Johansen maximum likelihood test for the stock markets of countries of Western Europe Region

\begin{tabular}{|c|c|c|c|c|}
\hline \multirow[t]{2}{*}{ Null hypothesis } & \multirow[t]{2}{*}{ Alternative hypothesis } & \multirow[t]{2}{*}{$\lambda$ trace value } & \multicolumn{2}{|c|}{ Critical values } \\
\hline & & & $5 \%$ & $1 \%$ \\
\hline$r=0^{* *}$ & $r>0$ & 390.31 & 291.4 & 307.64 \\
\hline$r \leq 1^{* *}$ & $r>1$ & 273.72 & 244.15 & 257.68 \\
\hline$r \leq 2^{*}$ & $r>2$ & 207.004 & 202.92 & 215.74 \\
\hline$r \leq 3$ & $r>3$ & 159.72 & 165.58 & 177.2 \\
\hline$r \leq 4$ & $r>4$ & 116.12 & 131.7 & 143.09 \\
\hline$r \leq 5$ & $r>5$ & 89.15 & 102.14 & 111.01 \\
\hline$r \leq 6$ & $r>6$ & 65.18 & 76.07 & 84.45 \\
\hline$r \leq 7$ & $r>7$ & 42.59 & 53.12 & 60.16 \\
\hline$r \leq 8$ & $r>8$ & 22.39 & 34.91 & 41.07 \\
\hline$r \leq 9$ & $r>9$ & 10.6 & 19.96 & 24.6 \\
\hline$r \leq 10$ & $r>10$ & 2.68 & 9.24 & 12.97 \\
\hline \multirow[t]{2}{*}{ Null hypothesis } & \multirow[t]{2}{*}{ Alternative hypothesis } & \multirow[t]{2}{*}{$\lambda$ max value } & \multicolumn{2}{|c|}{ Critical values } \\
\hline & & & $5 \%$ & $1 \%$ \\
\hline$r=0^{* *}$ & $r=1$ & 116.58 & 69.74 & 76.63 \\
\hline$r=1^{*}$ & $r=2$ & 66.71 & 63.57 & 69.94 \\
\hline$r=2$ & $r=3$ & 47.28 & 57.42 & 63.71 \\
\hline$r=3$ & $r=4$ & 43.59 & 52 & 57.95 \\
\hline$r=4$ & $r=5$ & 26.97 & 46.45 & 51.91 \\
\hline$r=5$ & $r=6$ & 23.97 & 40.3 & 46.82 \\
\hline$r=6$ & $r=7$ & 22.59 & 34.4 & 39.79 \\
\hline$r=7$ & $r=8$ & 20.19 & 28.14 & 33.24 \\
\hline$r=8$ & $r=9$ & 11.79 & 22 & 26.81 \\
\hline$r=9$ & $r=10$ & 7.91 & 15.67 & 20.2 \\
\hline$r=10$ & $r=11$ & 2.68 & 9.24 & 12.97 \\
\hline
\end{tabular}

* $(* *)$ denotes rejection of the hypothesis at the $5 \%,(1 \%)$ level respectively $r=$ No. of Cointegrating vectors

The null hypothesis of $(r=0)$ and $(r=1)$ is rejected against the alternative hypothesis of $(r=1)$ and $(r=2)$ at the $5 \%$ level of probability and the null hypothesis of $(r=0)$ is rejected against the alternative hypothesis of $(r=1)$ at the $1 \%$ level of probability. This shows the existence of some long run equilibrium relationships between the stock markets of the region.

\section{Conclusion}

Our motivation for this study is to analyze whether stock markets in Western Europe are indeed closely linked with other stock markets in the region; and how well the return distributions of these countries' stock markets are linked with world market.

The study attempts to capture the dynamics of short term linkages between the return distributions of stock markets in this region; what percentage of the forecast error variance of the return distribution of these stock markets is explained by themselves as well as by other stock markets of the region, both immediately and over a period of time; and how the short run disequilibria in the return distributions 
are corrected by the interaction of the return distributions of the other stock markets of the region. The study is also motivated to capture the long run stochastic trends of the market returns. By studying this, we not only extend previous research on exploring the time series properties of the return distributions in the region, but also evaluate the stock market integration of Western Europe.

In this paper, seventeen weekly stock markets returns we reinterpreted using VAR analysis to obtain insights in to the dynamic interconnections of regional stock markets. Emphasis was given to the mechanism by which shocks in one stock market are transmitted to other markets overtime. Our evidence indicates that a substantial amount of dynamism exists among the stock markets of Western Europe. Almost 58\% of the total stock markets of Western Europe are interlinked dynamically. Thus, it can be concluded that a proper transmission of information exists within the region. Moreover, Austria and the Netherlands are found to have the most influential stock markets in the Western European region in term of their capability to account for the error variances of other markets. This may reflect the dominant position of both these markets in the Western European region, which probably makes them the most important producers of information affecting the other stock markets of the region. MSCI is found to be dynamically interlinked with most of these stock markets and is also found to be significant in explaining the forecast error variances of some of these selected stock markets. This result implies that there will be no potential gain from portfolio diversification by stock managers. A significant error correction term implies that the short term disequilibrium in these countries' stock markets will be corrected significantly by the short term lagged differences of the other stock markets of the region. It is found that the ECTs are significant for the stock markets of Austria, Britain, Denmark, Finland, Germany, Greece, Italy, Norway, Portugal, Spain, Sweden, and Switzerland. The MSCI index is found to be significant with the region and these regional stock markets are found to be dynamically interlinked. Again, according to the findings from the Johansen maximum likelihood estimates, there exists a strong long run equilibrium relationship between the return distributions of the stock markets within the region. The stock markets returns are dynamically interlinked within the region both in the short term and the long term. This further confirms that the diversification of portfolios will not be a good strategy for the stock managers in the Western European region.

\section{Endnotes}

${ }^{1} \mathrm{~b}$ convergence is used to assess the convergence of stock market returns, whiles convergence is used to assess the convergence of stock market volatility. Both are used for evaluating the interdependence of stock markets.

${ }^{2}$ In a VAR framework, when past values significantly affect today's values, more lags will be necessary. In order to determine optimum lag length, several selection criteria can be used, such as the Akaike information criterion (AIC), Schwarz' Bayesian information criterion (SIC/BIC/SBIC), LR, and $\mathrm{HQ}$. These rules choose lag length $j$ to minimize the residual sum of squares for the proposed VAR model. 


\section{Appendix}

Table 6 Description of Stock Market Benchmark Indices of the Respective Countries

\begin{tabular}{|c|c|c|c|c|}
\hline SI. No & Countries & Index ticker & Name of the index & Description of index \\
\hline 1 & Austria(AUS) & ATX Index & $\begin{array}{l}\text { The Austrian } \\
\text { Traded Index }\end{array}$ & $\begin{array}{l}\text { The Austrian Traded Index is a capitalization- } \\
\text { weighted index of the most heavily traded } \\
\text { stocks on the Vienna Stock Exchange. The } \\
\text { equities use free float adjusted shares in the } \\
\text { index calculation. }\end{array}$ \\
\hline 2 & Belgium (BEL) & BEL20 Index & Belgium 20 Index & $\begin{array}{l}\text { The BEL } 20 \text { Index is a modified capitalization- } \\
\text { weighted index of the } 20 \text { most capitalized and } \\
\text { liquid Belgian stocks that are traded on the } \\
\text { Brussels Stock Exchange. }\end{array}$ \\
\hline 3 & Britain (BTN) & UKX Index & FTSE 100 Index & $\begin{array}{l}\text { The FTSE } 100 \text { Index is a capitalization-weighted } \\
\text { index of the } 100 \text { most highly capitalized } \\
\text { companies traded on the London Stock } \\
\text { Exchange. The equities use an invisibility } \\
\text { weighting in the index calculation. }\end{array}$ \\
\hline
\end{tabular}

KFMX Index Kfmx Copenhagen Share Index

$5 \quad$ Finland (FIN)

HEX Index

Helsinki Stock Exchange Gen. Index

The KFMX Index is a capitalization-weighted index which consists of the stocks of the small and medium-sized companies traded on the Copenhagen Stock Exchange.

The Helsinki Stock Exchange General Index

(Economic Sector) is a capitalization weighted index consisting of all the stocks traded on the exchange. The HEX Index is broken down using the GICS Classification as of July 1, 2005.

6 France (FRN)

CAC Index

CAC 40 Index

The CAC-40 Index is a narrow-based, modified capitalization-weighted index of 40 companies listed on the Paris Bourse.

DAX Index

German Stock Index

The German Stock Index is a total return index of 30 selected German blue chip stocks traded on the Frankfurt Stock Exchange. The equities use free float shares in the index calculation.

8

Greece (GRC)

ASE Index

Athens Stock Exch Gen. Index

The Athens Stock Exchange General Index is a capitalization-weighted index of Greek stocks listed on the Athens Stock Exchange. The index was developed with a base value of 100 as of December 31, 1980.

$9 \quad$ Ireland (IRL)

ISEQ Index

Irish Overall Index

The ISEQ Overall Index is a capitalizationweighted index of all Official list equities in the Irish Stock Exchange but excludes UK registered companies. The index has a base value of 1000 as of January 4, 1988.

10 Italy (ITL)

MIB30 index Milan MIB30 Index

The MIB 30 is a capitalization-weighted index of the 30 top Italian companies traded on the Milan Stock Exchange. This index is based on a current market capitalization-weighted methodology.

11 Luxembourg (LXM) LUX XX

Luxembourg X Index

$$
x
$$

The Luxembourg (Lux) X Index is a weighted index of the most capitalized (by free- float) and liquid Luxembourg stocks. The index was developed with a base value of 1,000 as of January 4, 1999.

Amsterdam Exchanges Index

The AEX-Index is a free-float adjusted market capitalization weighted index of the leading Dutch stocks traded on the Amsterdam Exchange. The index was adjusted to the Dutch Guilder fixing rate.

13 Norway (NRY) OBX OBS Stock Index
The OBX Index is a capitalization-weighted index of the largest companies traded on the Oslo Stock Exchange. The equities use free float shares in the index calculation. 
Table 6 Description of Stock Market Benchmark Indices of the Respective Countries (Continued)

\begin{tabular}{|c|c|c|c|c|}
\hline 14 & Portugal (PRT) & PSI20 & Portugal 20 Index & $\begin{array}{l}\text { The PSI } 20 \text { Index is a capitalization weighted } \\
\text { index of the top } 20 \text { stocks listed on the } \\
\text { Lisbon Stock Exchange. The equities use free } \\
\text { float shares in the index calculation. }\end{array}$ \\
\hline 15 & Spain (SPN) & IBEX & IBEX 35 Index & $\begin{array}{l}\text { The IBEX } 35 \text { is the official index of the Spanish } \\
\text { Continuous Market. The index is comprised of } \\
\text { the } 35 \text { most liquid stocks traded on the } \\
\text { Continuous market. It is calculated, supervised } \\
\text { and published by the Sociedad de Bolsas. }\end{array}$ \\
\hline 16 & Sweden (SWN) & OMX & $\begin{array}{l}\text { OMX Stockholm } \\
30 \text { Index }\end{array}$ & $\begin{array}{l}\text { The OMX Stockholm } 30 \text { Index is a } \\
\text { capitalization-weighted index of the } 30 \text { stocks } \\
\text { that have the largest volume of the trading } \\
\text { on the Stockholm Stock Exchange. The equi- } \\
\text { ties use free float shares in the index } \\
\text { calculation. }\end{array}$ \\
\hline 17 & Switzerland (SWZ) & SMI & Swiss Market Index & $\begin{array}{l}\text { The Swiss Market Index is a capitalization- } \\
\text { weighted index of the } 20 \text { largest and most } \\
\text { liquid stocks of the SPI universe. It represents } \\
\text { about } 85 \% \text { of the free- float market } \\
\text { capitalization of the Swiss equity market. }\end{array}$ \\
\hline 18 & World Index (MSCI) & $\mathrm{MSCl}$ & $\begin{array}{l}\text { Morgan Stanly } \\
\text { Capital Inter. } \\
\text { World Index }\end{array}$ & $\begin{array}{l}\text { MSCI World Index has been calculated since } \\
1969 \text { with gross dividends reinvestable. It is a } \\
\text { stock market Index of } 1500 \text { world stocks of } \\
\text { both developed and emerging countries. }\end{array}$ \\
\hline
\end{tabular}

\section{Acknowledgement}

The authors are grateful to the anonymous referees of the journal for their extremely useful suggestions to improve the quality of the article. The usual disclaimer applies.

\section{Funding}

This research received no specific grant from any funding agency in the public, commercial, or not-for-profit sectors.

\section{Authors' contribution}

We have no conflicts of interest to disclose. Both the authors contributed equally to this work. Both authors read and approved the final manuscript

\section{Competing interests}

The authors declare that they have no competing interests.

\section{Author details}

${ }^{1}$ National Institute of Industrial Engineering, Powai, Mumbai, India. ${ }^{2}$ School of Economics, University of Hyderabad, Central University, Gachibowlli, Hyderabad 500046, Telengana, India.

Received: 18 September 2016 Accepted: 7 December 2016

Published online: 06 January 2017

\section{References}

Babetskii I, Komarek L, Komarkova Z (2007) Financial integration of stock markets among new EU member states and the euro area. Czech J Econ Financ 57:341-362

Chung P, Lin D (1994) Commonstochastic trends in the Pacific stock markets. Q Rev Econ Finance 34:241-259

Corhay A, Tourani R, Urbain J-P (1995) Long-run behaviour of Pacific-basin stock prices. Appl Financ Econ 5:11-18

Egert B, Kocenda E (2007) Interdependence between Eastern and Western European stock markets: evidence from intraday data. Econ Syst 31:184-203

Enders W (1995) Applied Econometric Time Series, John Wiley \& Sons, Inc., New York

Engel RF, Granger CWJ (1987) Co-Integration and Error Correction: Representation, Estimation and Testing. Econometrica. 55(2):251-276

Eun CS, Shim S (1989) International transmission of stock market movements. J Financ Quant Anal 24(2):241-256

Gilmore C, McManus G (2002) International portfolio diversification: US and Central European equity markets. Emerg Mark Rev 3:69-83

Gilmore C, McManus G (2003) Bilateral and multilateral cointegration properties between the German and Central European equity markets. Studies in Economics and Finance 21:40-53

Horvath R, Petrovski D (2013) International stock market integration: Central and South Eastern Europe compared. Econ Syst 37:81-91

Hsiao C (1981) Autoregressive modelling and money-income causality detection. J Monet Econ 7(1):85-106

Johansen (1988) Statistical analysis of cointegration vectors. J Econ Dyn Control, Elsevier, 12(2-3):231-254 
Johansen S, Juselius K (1990) Maximum Likelihood Estimation and Inference on Cointegration- with Applications to the Demand for Money. Oxf Bull Econ Stat 52(2):169-210

Kasa K (1992) Common stochastic trends in international stock markets. J Monet Econ 29(1):95-124

Kocenda E, Egert B (2011) Time-varying synchronization of European stock markets. Empir Econ 40:393-407

Masih A, Masih R (1999) Are Asian stock market fluctuations due mainly to intra-regional contagion effects? Evidence based on Asian emerging stock markets. Pac Basin Financ J 7:251-282

Onay, C. (2006), "A Co-integration Analysis Approach to European Union Integration: The Case of Acceding and Candidate Countries", European Integration Online Papers (EloP), 10(7):01-16

Phylaktis K, Ravazzolo F (2002) Measuring financial and economic integration with equity prices in emerging markets. J Int Money Financ 21(6):879-903

Phylaktis K, Ravazzolo F (2005) Stock market linkages in emerging markets: implications for International portfolio diversification. Int Financ Mark Inst Money 15:91-106

Samitas A, Kenourgios D (2011) Equity market integration in emerging Balkan markets. Res Int Bus Financ 25:296-307

Scheicher M (2001) The comovements of stock markets in Hungary, Poland and the Czech Republic. Int J Financ Econ 6:27-39

Syriopoulos T (2004) International portfolio diversification to Central European stock markets. Appl Financ Econ 14:1253-1268

Vizek M, Dadic T (2006) Integration of Croatian, CEE and EU equity markets: cointegration approach. Ekonomski pregled $57: 631-646$

Voronkova S (2004) Equity market integration in Central European emerging markets: a cointegration analysis with shifting regimes. Int Rev Financ Anal 13:633-647

Submit your manuscript to a SpringerOpen ${ }^{\circ}$ journal and benefit from:

- Convenient online submission

- Rigorous peer review

- Immediate publication on acceptance

- Open access: articles freely available online

- High visibility within the field

- Retaining the copyright to your article

Submit your next manuscript at $>$ springeropen.com 